\title{
Pendampingan Usaha BUMDes Maju Jaya "BMJ" Desa Sawiji, Kecamatan Diwek, Kabupaten Jombang
}

\author{
Kristin Juwita $^{1 *}$, Erminati Pancaningrum ${ }^{2}$ \\ STIE PGRI Dewantara Jombang \\ Korespondensi*: Kristinjuwita66@gmail.com
}

Diserahkan: 1 November 2018, Direvisi: 25 Desember 2018, Diterima: 8 September 2018

abstrak

\begin{abstract}
Program pengabdian masyarakat dilakukan di desa Sawiji pada badan usaha milik desa (BUMDEs) yang beroperasi dibidang usaha popcorn dan arum manis. Permasalahan yang ditemukan adalah produk belum memiliki ijin Produksi Industri Rumah Tangga (PIRT) sehingga konsumen masih khawatir terkait keamanan bahan baku dan higienitas proses produksi. Adapun permasalahan diselesaikan dengan membantu memfasilitasi pengurus BUMDes mendaftar ijin Produksi Industri Rumah Tangga (PIRT) setela sebelumnya ada perbaikan dalam hal pembuatan label da merk produk sebagai syarat kelengkapan pengurusan ijin. Setelah melakukan pendaftaran ijin, pengurus dapat menunggu jadwal sosialisasi dan survey lokasi.
\end{abstract}

Kata kunci: Pendampingan, Badan usaha milik desa (BUMDEs), PIRT

abstract

Community service programs are conducted in Sawiji village at village owned enterprise (BUMDEs) that producing popcorn and cotton candy. Problem that occur is product have not permit of Household Production Industry (PIRT) so the consumers are still worried about the raw material security and hygienity of production process. The problem solved by facilitate the management of BUMDes to register Production License of Household Industry (PIRT) after improvement the label and brand to complete the permit appication. After register the permit next stage is wait for socialization schedule and site survey.

Keyword: Accompaniment, village owned interprise (BUMDEs), Household Production Industry (PIRT)

\section{A. PENDAHULUAN}

\section{Latar Belakang}

Salah satu kewajiban Dosen di lingkungan Perguruan Tinggi dalam melaksanakan tri dharma perguruan tinggi adalah melaksanakan kegiatan pengabdian kepada masyarakat. Melalui pengabdian masyarakat, diharapkan para dosen dapat menerapkan ilmu pengetahuan dan kompetensi yang dimiliki untuk membantu masyarakat. Dalam hal ini, kegiatan pengabdian difokuskan pada pendampingan masyarakat terkait pemahaman pengelolaan BUMDes (Badan Usaha Milik Desa) yang masih sangat diperlukan. BUMDes dibentuk pemerintah sebagai instrumen yang merupakan modal sosial (social capital) dalam menjembatani upaya penguatan ekonomi di pedesaan.

Badan Usaha Milik Desa (BUMDes) adalah lembaga usaha yang bergerak dalam bidang pengelolaan aset-aset dan sumberdaya ekonomi desa dalam kerangka pemberdayaan masyarakat desa, (Dewi, 2014). Meskipun sudah berjalan beberapa tahun, BUMDes ternyata memiliki hambatan mulai dari permodalan, payung hukum, kepengurusan yang tidak berjalan, dan implementasi kegiatan yang berhenti. Menurut (Dewi, 2014) permasalahan legalitas bentuk badan hukum yang tepat ternyata menjadi masalah yang lebih besar bagi 
pendirian BUMDes. Meskipun di beberapa daerah Kabupaten/Kota telah memiliki Perda yang mengatur tentang Tata Cara Pembentukan dan Pengelolaan Badan Usaha Milik Desa (BUMDes), tetapi seringkali di beberapa Perda tersebut terjadi ketidaktepatan dalam memilih konstruksi badan hukum yang tepat bagi BUMDes. Bahkan kasus yang sering terjadi, BUMDes tidak menggunakan bentuk badan hukum, melainkan "hanya" berbentuk badan usaha yang tidak berbadan hukum. Padahal ketentuan pasal 78 ayat (3) Peraturan Pemerintah Nomor 72 Tahun 2005 tentang Desa menyatakan bahwa Bentuk Badan Usaha Milik Desa harus berbadan hukum.

Jenis kegiatan BUMDes sebagaimana diatur dalam pasal 12 dan 13 Peraturan Menteri Dalam Negeri Nomor 39 Tahun 2010 tentang Badan Usaha Milik Desa. Badan usaha milik desa (BUMDes) setiap daerah memiliki produk usaha yang berbeda-beda. Hal ini, disesuaikan dengan potensi desa dan kemampuan pengurusnya. Mayoritas BUMDes berupa simpan pinjam, namun ada juga yang mengelola dalam bentuk usaha kecil menengah (UKM) atau desa wisata. Adapun desa Sawiji misalnya, BUMDes yang dikelola berfokus pada usaha popocorn dan arum manis atau yang terkenal dengan sebutan "rambut nenek".

Pengelolaan BUMDes di desa Sawiji diserahkan pada pengurus dengan pengawasan dan pengendalian dari kepala desa. Dalam proses produksi dan pemasaran produk sudah berjalan lancar, namun terdapat kendala yang dihadapi yaitu produk belum masih memiliki ijin produksi dari dinas kesehatan atau BPOM sehingga masyarakat masih khawatir jika produk makanan tersebut tidak higienis atau mengandung zat kimia berbahaya. Selain itu, kemasan produk juga kurang menarik sehingga konsumen kurang tertarik untuk membeli. Maka dari itu, kami mengadakan pendampingan khususnya memfasilitasi pengusaha popcorn dan arum manis minimal untuk mendapat ijin PIRT (Produksi Industri Rumah Tangga) dari Dinas Kesehatan.

\section{Tujuan dan Manfaat}

Tujuan dilakukan pendampingan adalah agar pengurus BUMDes dapat memproduksi popcorn dan arum manis dengan harga terjangkau namun tetap memenuhi standar kualitas produksi melalui pendaftaran ijin PIRT (Produksi Industri Rumah Tangga) dan adanya inovasi kemasan produk yang menarik, serta menghasilkan merk produk yang mudah dikenal konsumen.

Diharapkan dengan adanya pendampingan pada badan usaha milik desa "Maju Jaya" mampu bermanfaat menggerakkan dinamika perekonomian desa dan sebagai agen pembangunan daerah serta menjadi pendorong terciptanya unit usaha kecil dan menengah tetapi dengan biaya produksi dan pengelolaan tidak terlalu besar.

\section{B. TINJAUAN PUSTAKA \\ 1. Desa}

Definisi Desa menurut PP No 72 tahun 2005 adalah kesatuan masyarakat hukum yang memiliki batas-batas wilayah yang berwenang untuk mengatur dan mengurus kepentingan masyarakat setempat, berdasarkan asal-usul dan adat istiadat setempat yang diakui dan dihormati dalam sistem Pemerintahan Negara Kesatuan Republik Indonesia (NKRI). PP No 72 tahun 2005 juga memberikan kewenangan yang cukup besar bagi kepala desa dalam melaksanakan tugas sebagai kepala pemerintahan desa. Kewenangankewenangan bagi kepala desa tersebut adalah: 
a) Memimpin penyelenggaraan pemerintahan berdasarkan kebijakan yang ditetapkan bersama Badan Permusyawaratan Desa (BPD).

b) Mengajukan rancangan Peraturan Desa (Perdes).

c) Menetapkan Peraturan Desa yang telah mendapat persetujuan bersama BPD.

d) Menyusun dan mengajukan rancangan peraturan desa mengenai Anggaran Pendapatan dan Belanja Desa(APBDesa) untuk dibahas dan ditetapkan bersama BPD.

e) Membina kehidupan masyarakat desa.

f) Membina perekonomian desa.

g) Mengkoordinasikan pembangunan desa secara partisipatif.

h) Mewakili desanya di dalam dan di luar pengadilan dan dapat menunjuk kuasa hukum untuk mewakili sesuai dengan peraturan perundang undangan.

i) Melaksanakan wewenang lain sesuai dengan peraturan perundang undangan.

\section{Badan Usaha Milik Desa (BUMDes)}

Menurut (Dewi, 2014) pengaturan BUMDes diatur di dalam pasal Pasal 213 ayat (1) UU No. 32 Tahun 2004, bahwa Desa dapat mendirikan Badan Usaha Milik Desa sesuai dengan kebutuhan dan potensi desa. Selain itu juga diatur dalam Peraturan Pemerintah Nomor 72 Tahun 2005 tentang Desa, yang didalamnya mengatur tentang BUMDes, yaitu pada Pasal 78 - 81, Bagian Kelima tentang Badan Usaha Milik Desa, serta yang terakhir dalam Peraturan Menteri Dalam Negeri Nomor 39 Tahun 2010 tentang Badan Usaha Milik Desa. Berarti hal ini diamanatkan bahwa dalam meningkatkan pendapatan masyarakat dan desa, pemerintah desa dapat mendirikan Badan Usaha Milik Desa (BUMDes) sesuai dengan kebutuhan dan potensi desa. Dalam hal perencanaan dan pembentukannya, BUMDes dibangun atas prakarsa (inisiasi masyarakat), serta mendasarkan pada prinsip-prinsip kooperatif, partisipatif dan emansipatif, dengan dua prinsip yang mendasari, yaitu member base dan self help. Hal ini penting mengingat bahwa profesionalime pengelolaan benar-benar didasarkan pada kemauan (kesepakatan) masyarakat banyak (member base), serta kemampuan setiap anggota untuk mandiri dalam memenuhi kebutuhan dasarnya (self help), baik untuk kepentingan produksi (sebagai produsen) maupun konsumsi (sebagai konsumen) harus dilakukan secara profesional dan mandiri (C B Ramadana, (2013)) .

Organ BUMDes telah diatur secara khusus dalam pasal 6 dan 7 Peraturan Menteri Dalam Negeri Nomor 39 Tahun 2010 tentang Badan Usaha Milik Desa yaitu: Pasal 6 : "Organisasi pengelola BUMDes terpisah dari organisasi pemerintahan desa." Pasal 7 : (1) Organisasi pengelola BUMDes sebagaimana dimaksud dalam Pasal 6, paling sedikit terdiri atas: (a) penasihat atau komisaris; dan (b) pelaksana operasional atau direksi; (2) Penasihat atau komisaris sebagaimana dimaksud pada ayat (1) huruf a, dijabat oleh Kepala Desa; dan (3) Pelaksana operasional atau direksi sebagaimana dimaksud pada ayat (1) huruf b, terdiri atas: (a) direktur atau manajer; dan (b) kepala unit usaha.

\section{Jenis-jenis BUMDes}

Jenis kegiatan usaha BUMDes disesuaikan dengan potensi ekonomi masyarakat desa dan memiliki prospek usaha yang baik. Jenis kegiatan BUMDes sebagaimana diatur dalam pasal 12 dan 13 Peraturan Menteri Dalam Negeri Nomor 39 Tahun 2010 tentang Badan Usaha Milik Desa dapat berupa: a) jasa, b) penyaluran sembilan bahan pokok, c) perdagangan

Comvice, Vol 3 No 1, April 2019

http://ejournal.stiedewantara.ac.id/index.php/COMVICE/issue/view 
hasil pertanian, dan/atau d) industri kecil dan rumah tangga. Pemilihan jenis kegiatan BUMDes tersebut dikelompokkan menjadi Unit Usaha Desa, dan pemilihannya dilakukan melalui musyawarah desa.

\section{METODE PENDAMPINGAN}

Adapun metode yang digunakan pada pendampingan ini adalah:

1. Observasi ke Balai Desa Sawiji. Tim pendamping melakukan wawancara dengan kepala desa Sawiji terkait informasi tentang pengurus BUMDes dan kegiatan usaha BUMDes.

2. Koordinasi awal. Tim pendamping berkoordinasi dengan pengurus BUMDes terkait proses produksi dan hambatan yang dihadapi.

3. Survey tempat produksi popcorn dan arum manis. Tim pendamping bersama pengurus menuju tempat produksi yang letaknya bersebelahan dengan rumah pengurus BUMDes untuk melihat alur produksi popcorn dan arum manis.

4. Koordinasi lanjutan. Dilakukan satu kali kunjungan. Selanjutnya, karena kesibukan, koordinasi berlanjut melalui telepon dan whatsapp.

5. Pendaftaran Ijin PIRT. Tim pendamping hanya sebagai fasilitator yang membantu informasi dan mengantar pengurus BUMDEs mendafatarkan ijin PIRT (Produksi Industri Rumah Tangga) sesuai persyaratan yang sudah dipersiapkan, karena yang menjalani sosialisasi dan menghadapi surveyor dari dinas kesehatan adalah pendaftar sendiri.

6. Monitoring. Monitoring yang dilakukan sementara ini dilakukan untuk mendapat kejelasan informasi waktu pelaksanaan sosialisasi oleh dinas kesehatan.

\section{HASIL DAN PEMBAHASAN}

Program pengabdian masyarakat di laksanakan pada semester genap 2017/2018 di Desa Sawiji yang terletak di dusun Kemiri Galih, Sawiji, Jogoroto, Jawatimur. Mayoritas mata pencaharian masyarakatnya adalah petani dan wirausaha. Badan Usaha Milik Desa (BUMDes) di desa sawiji beroperasi pada jenis usaha kecil menengah yaitu produksi dan pemasaran produk popcorn dan arum manis. Dengan modal awal dari dana BUMDes dibelikan mesin produksi, bahan baku, dan baiya tenaga kerja serta kebutuhan lain.

Pada kunjungan ke-1, dilakukan wawancara dengan kepala desa terkait alasan mengelola BUMDes di bidang UMKM. Diperoleh informasi yaitu usaha simpan pinjam yang dulu pernah ada di koperasi desa tidak berjalan baik. Maka dikhawatirkan jika dana BUMDes digunakan untuk usaha simpan pinjam tidak efektif. Adapun rencana awal kepala desa adalah ingin membuat sebuah desa wisata yang kebetulan ada waduk yang bisa di kombinasikan dengan taman atau kolam renang anak. Namun impian ini masih terhambat besarnya dana atau yang dibutuhkan. Akhirnya terdapat ide memberdayakan usaha masyarakat melalui program BUMDes "Maju Jaya" yang memproduksi popcorn dan arum manis. Ide ini muncul karena desa sawiji belum mempunyai produk khas selayaknya desa kedawong terkenal dengan usaha tape ketan, desa bandung terkenal dengan permen tape dan usaha lele dan gurame, desa jatirejo mulai terkenal dengan usaha jenang salak dan sari salak.

Setelah diperoleh informasi dari kepala desa maka selanjutnya dilakukan koordinasi dengan tim pengurus BUMDes pada kunjungan ke-2. Pengurus BUMDes terdiri dari direktur yaitu bapak supiadi, sekretaris yaitu bapak adi, dan bendahara yaitu bapak sudarman. Mata pencaharian pengurus BUMDes nya adalah pedagang di pasar peterongan sehingga membuat tim harus menyesuaikan waktu. Dalam koordinasi awal diperoleh informasi dari pengurus 
bahwa usaha popcorn sudah ada, namun masih kecil karena terkendala modal. Dengan adanya BUMDes "Maju Jaya" maka usaha popcorn lebih lancar dan ditambah produk usaha arum manis. Dari segi mesin produksi dan sumber daya manusia sudah terpenuhi. Dalam hal pemasaran produk masih terbatas wilayah jombang saja, itupun dengan sistem titip-jual ke toko-toko dan dijual oleh pedagang ke sekolah-sekolah.

Di kunjungan ke-3, tim bertemu dengan pengurus BUMDes untuk melihat proses produksi popcorn dan arum manis. Tenaga kerja yang memproduksi hanya 4 orang. 2 orang memproduksi popcorn dan 2 orang lainnya memproduksi arum manis. Dalam hal produksi:

a. Popcorn.

- Popcorn terbuat dari jagung khusus popcorn, mentega, gula pasir, garam, pewarna makanan.

- Proses pengolahan popcorn yaitu dengan memannaskan panci atau penggorengan, selanjutnya masukan mentega dan sedikit minyak sesuai takaran jagung yang akan di goreng (misal: 2 sendok mentega untuk 2 genggam jagung). Setelah mentega meleleh maka kecilkan api dan masukan jagung ke dalam panci. Segera tutup panci dan goyang-goyangkan panci sesekali agar jagung terkena mentega dengan rata. Biarkan hingga letupan jagung selesai. Baru matikan kompor. Buka tutup panci dan tambahkan gula atau garam dan pewarna makanan secukupnya kemudian tutup panci dan goyang-goyangkan biar rata. Untuk gula/garam/caramel/pewarna makanan sebaiknya cair agar mudah dalam mencampurkan dengan popcorn.

- Adapun popcorn di BUMDes "Maju Jaya" menggunakan gula pasir yang sudah dicairkan dengan rasa strawbery dan coklat yang berasal dari pasta.

b. Arum Manis "Rambut Nenek"

- Arum manis terbuat dari gula (Gulaku), pewarna makanan, air.

- Proses pembuatan arum manis yaitu campur gula, air, dan pewarna makanan sesuai takaran. Panaskan mesin pembuat arum manis. Jika sudah panas, masukan gula dan pewarna yang sudah tercampur tadi dalam mesin dan tunggu beberapa saat sampai muncul serabut gula yang keluar. Gulung dengan gerakan memutar sesuai ukuran kemasan. Jika sudah sesuai takaran maka dapat dimasukan dalam kemasan agar tidak terpapar udara langsung, sehingga tidak mengeras. 


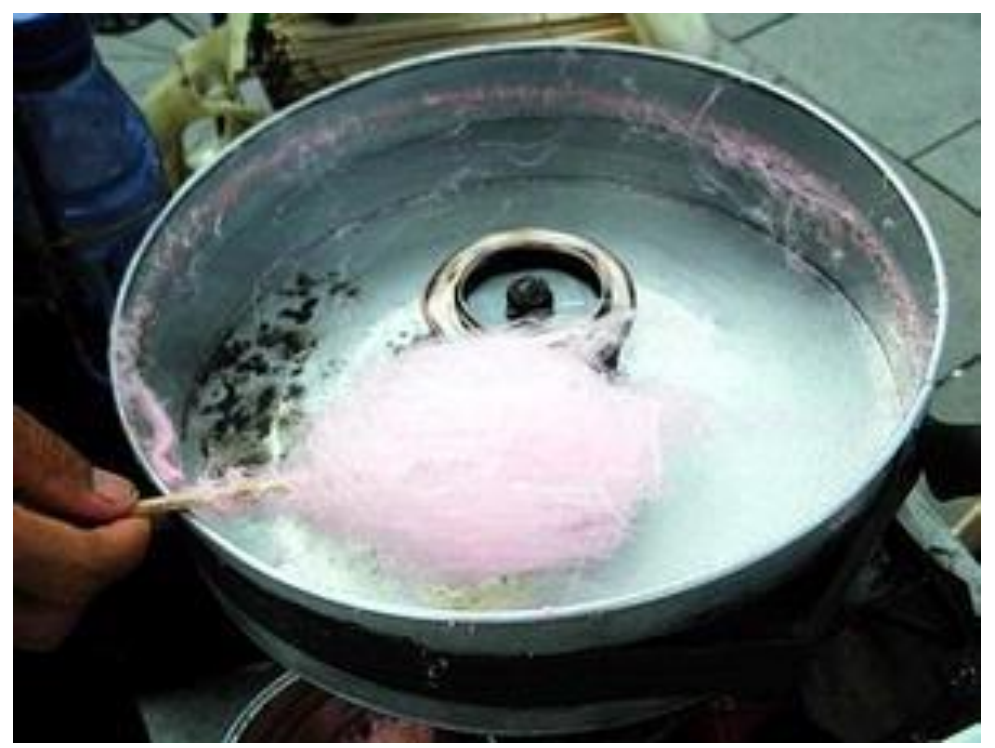

Gambar 1. Mesin Pengolah Arum Manis

Pada kunjungan ke-4 dilakukan koordinasi lanjutan terkait manajemen BUMDes "Maju Jaya". Dari hasil wawancara dengan pengurus BUMDes diperoleh informasi bahwa Pengurus ini mendaftar ijin PIRT (Produksi Industri Rumah Tangga) namun belum mengetahui apa saja persyaratannya dan bagaimana prosedurnya. Sehingga tim mencoba membantu mencarikan informasi melalui dinas kesehatan. Adapun syarat nya yaitu:

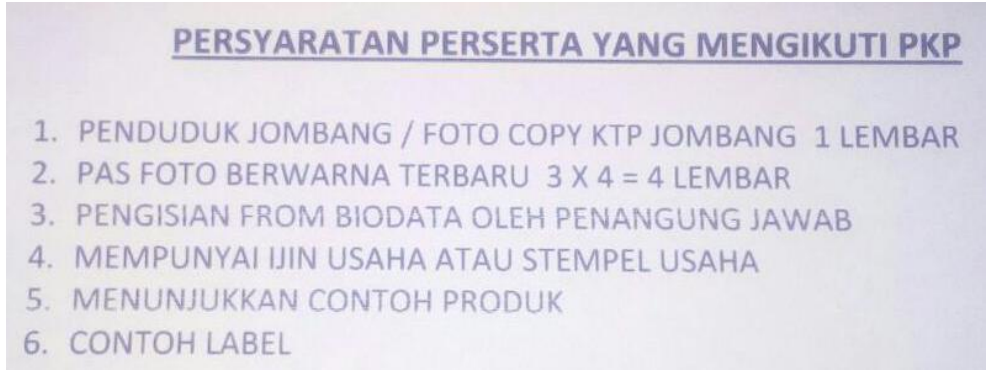

Gambar 2. Persyaratan pendaftaran ijin PIRT

Berdasarkan persyaratan pada gambar diatas, pengurus BUMDes memiliki label popcorn namun hanya sederhana dan tanpa merk, sebagai berikut:

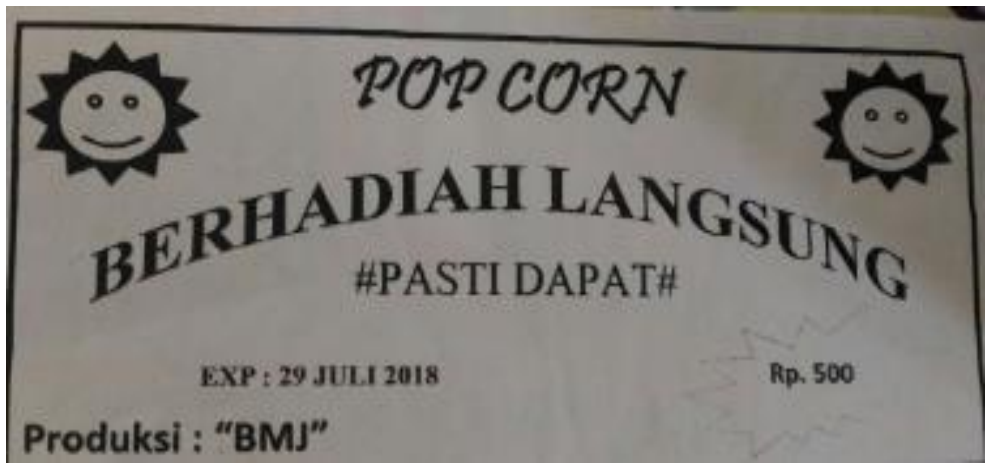

Gambar 3. Label produk popcorn yang lama 
Sedangkan untuk label arum manis belum punya, sehingga tim mencoba membantu membuatkan label dan merk yang menarik dan memenuhi syarat, sebagai berikut:
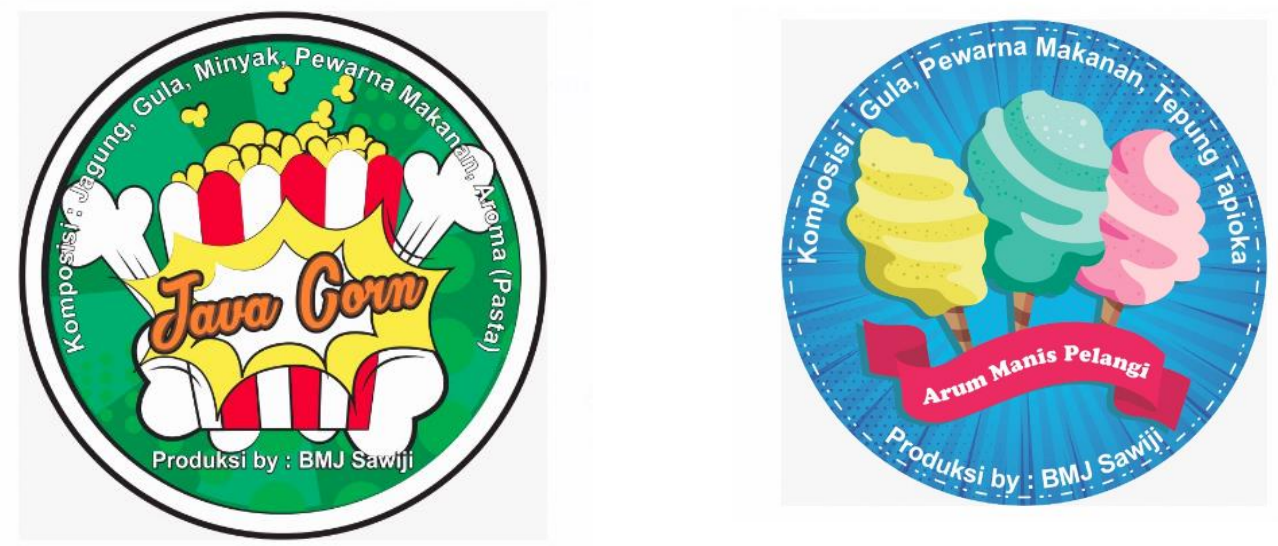

\section{Gambar 4. Label pop corn “ Java Corn” Gambar 5. Label “Arum manis Pelangi”}

Pada kunjungan ke- 5 tim mengantar pengurus BUMDes untuk mendaftarkan ijin Produksi Industri Rumah Tangga (PIRT) . Namun dalam hal ini, tim pendamping hanya sebagai fasilitator yang membantu informasi dan mengantar pengurus BUMDEs mendafatarkan ijin PIRT (Produksi Industri Rumah Tangga) sesuai persyaratan yang sudah dipersiapkan, karena nanti yang menjalani sosialisasi dan menghadapi surveyor dari dinas kesehatan adalah pendaftar sendiri.

Dalam hal monitoring, tim berkoordinasi melalui telepon dan whatsapp. Hal ini sementara ini dilakukan untuk mendapat kejelasan informasi dari dinas kesehatan terkait undangan jadwal pelaksanaan sosialisasi pada para pendaftar ijin Produksi Industri Rumah Tangga (PIRT).

\section{E. PENUTUP}

Berdasarkan hasil pendampingan pengurusan ijin Produksi Industri Rumah Tangga (PIRT), pada periode ini berjalan lancar. Hal ini terlihat dari adanya keterbukaan informasi dan dukungan dari kepala desa dan pengurus BUMDes dalam memperbaiki produk usaha BUMDes mereka. Namun, pendampingan ini masih belum tuntas dan akan berlanjut pada periode berikutnya. Hal ini dikarenakan daftar tunggu sosialisasi yang panjang karena hanya ada 3 kali dalam satu tahun dengan jumlah peserta terbatas. Selanjutny diharapkan pemasaran produk popcorn dan arum manis akan lebih baik dengan didukung pengelolaan yang higienis dan kemasan baru yang menarik. Selain itu, pendampingan dapat dilanjutkan pada perbaikan manajemen administrasi "BMJ" atau BUMDes "Maju jaya".

\section{DAFTAR PUSTAKA}

Undang - Undang Nomor 32 Tahun 2004 tentang Pemerintah Daerah. Jakarta, Direktoral Jenderal Otonomi Daerah. 
Peraturan Pemerintah Nomor 72 Tahun 2005 tentang Desa. Jakarta, Direktorat Jenderal Otonomi Daerah.

C B Ramadana, H. R. ((2013)). Keberadaan Badan Usaha Milik Desa (BUMDES) sebagai Penguatan Ekonomi Desa. Jurnal Administrasi Publik , 6, 1068-1076.

Dewi, A. S. (2014). Peranan Badan Usaha Milik Desa (Bumdes) Sebagai Upaya Dalam Meningkatkan Pendapatan Asli Desa (Pades) Serta Menumbuhkan Perekonomian Desa. Journal of Rural and Developmen, 5 (1). 